\title{
BOOK REVIEW: MEDIA LAW IN NEW ZEALAND
}

\author{
Steven Price*
}

John Burrows and Ursula Cheer Media Law in New Zealand (5 ed, Oxford University Press, Melbourne, 2005) (655 + Ixxvii Pages).

In the preface to the first edition of this book, published in 1974, Professor Burrows wrote that he was "struck by how much material of interest to the journalist is scattered among works on other areas of the law, and indeed how much has never been written about at all."1 Back then, as Geoffrey Robertson and Andrew Nicol noted recently, "there was no academic or professional acknowledgement that 'media law' might exist as a subject worthy of separate and coherent study."2

The emergence of media law as a legitimate field of study, in this country anyway, owes much to this book. ${ }^{3}$ Professor Burrows, joined by his University of Canterbury colleague Ursula Cheer, has painstakingly mapped out the media law landscape. They have fossicked through thickets of statutes to chart (among many other things) powers to suppress information and avenues to uncover it. They have roamed through common law fields to mark out potholes for unwary journalists, such as defamation, contempt, privacy, and negligent misstatement. They have waded through streams of administrative law to record the currents affecting the media, including decisions on broadcasting standards and rulings on censorship. It is a huge task, and everyone with an interest in media law students, journalists, academics, practitioners and judges alike - ought to be deeply grateful to them for it. The result is a lucid and comprehensive compilation of the disparate laws affecting the media in New Zealand, and some significant steps toward making sense of media law as a whole.

Such is the rate of growth of media law in the last thirty years that the latest edition is more than twice the length of its 1974 counterpart. It refers to more than two and a half times as many

* Fellow in Law and Journalism, School of Law, Victoria University of Wellington.

1 John F Burrows News Media Law in New Zealand (Sweet \& Maxwell, Wellington, 1974) v.

2 Geoffrey Robertson and Andrew Nicol Robertson and Nicol on Media Law (4 ed, Sweet and Maxwell, London, 2002) xi.

3 John Burrows and Ursula Cheer Media Law in New Zealand (5 ed, Oxford University Press, Melbourne, 2005). 
statutory provisions and regulations. It cites more than three times as many cases. (Amazingly, just over a quarter of the cases cited in the 2005 edition have been decided since the publication of the last edition, in 1999.) And yet, in some ways, the scope of the 2005 version is narrower than the 1974 one: for instance, there is no chapter on advertising.

In 1974, Professor Burrows noted there was clamour for reform of some of the laws affecting the media: reputations were too well protected by harsh defamation laws; privacy was barely protected at all. ${ }^{4}$ Successive editions of this book have traced the gradual redress of both problems. The sharp edge of defamation law has been blunted by a series of reforms in the Defamation Act 1992 and - at least in the arena of political speech - by the expanded defence of qualified privilege in Lange $v$ Atkinson. ${ }^{5}$ On the other hand, privacy protections have blossomed, most notably in the Privacy Act 1993, the Broadcasting Act 1990 and the Court of Appeal's decision in Hosking $v$ Runting. ${ }^{6}$ Burrows and Cheer welcome both developments, but are alive to the difficulties they create for journalists and their lawyers.

In particular, they cast a wary eye on the mixed fortunes of journalists in the United Kingdom who have looked to utilise the expanded qualified privilege there. ${ }^{7}$ Claims of privilege have crumbled in the face of attacks on the reasonableness of journalistic conduct: in particular the unreliability of sources, the vagueness of allegations, or failures to properly verify information or offer the subject an opportunity to comment. ${ }^{8}$ Asked to assess reporters' reasonableness, lawyers and courts readily find them wanting, it seems.

Nor is qualified privilege the only area in which standards of reasonableness (or "responsibility") are insinuating their way into media law. If the media breach someone's reasonable expectation of privacy, they may be sued. ${ }^{9}$ Reporters who fail to make reasonable inquiries before publishing contentious confidential material risk losing a public interest defence in an action for breach of confidence. ${ }^{10}$ The reasonableness of a news organisation's belief in the genuineness of a contributor or source may affect the availability of an honest opinion defence in defamation. ${ }^{11}$

4 Burrows, above n 1, 11-12.

5 The last instalment being Lange v Atkinson [2000] 3 NZLR 385 (CA).

$6 \quad$ Hosking $v$ Runting [2005] 1 NZLR 1 (CA).

7 Reynolds $v$ Times Newspapers Ltd [2001] 2 AC 127 (HL).

8 See, for example, Jameel v Wall Street Journal SPRL [2003] EWHC 2322; Loutchansky v Times Newspapers (No 4) [2002] All ER (D) 371.

9 Hosking $v$ Runting, above n 6.

10 Attorney-General v Guardian Newspapers Ltd (No. 2) [1988] 3 All ER 545, 560 (Ch) Scott J.

11 Defamation Act 1992, s 10(2). 
When judges rule on issues of reasonableness, as Burrows and Cheer note, they create precedents that "have tended to become definitive codes or guidelines." Key factors in decisions become fixed rules for journalists looking to avoid lawsuits. As reasonableness standards permeate media law, this evokes the spectre of judicially created de facto codes of journalistic ethics.

Generally, however, the authors elucidate the law rather than evaluate it. They are concerned to help journalists and media lawyers navigate their way around legal pitfalls, and focus on providing practical advice. "Attend the trial personally," they tell court reporters. ${ }^{12}$ Separate fact from opinion, they advise editors. Always argue fairness as well as privacy, they sensibly suggest to Broadcasting Standards Authority complainants.

This guidance is invaluable, especially as much of media law imposes strict liability. News organisations must brave laws of defamation, contempt, breach of confidence and privacy - as well as broadcasting standards - knowing that innocent mistakes will not be excused.

It is not surprising that the media have looked toward the guarantee of freedom of expression in the New Zealand Bill of Rights Act 1990 (BORA) to ameliorate the harshness of these laws. ${ }^{13}$ The BORA "ensures - or, rather, should ensure that those responsible for developing and applying the law ask whether an intrusion on freedom of expression is truly justified," the authors say. ${ }^{14}$ They observe that the BORA tends to get "generous mention" in the case law, but "a more restrictive outcome than in some other countries." 15 They are surely right. The examination of the free speech issues that arise during the legislative vetting process is seldom more than cursory. Blanchard $\mathrm{J}$ ruled in 1994 that a copyright infringement case raised no free speech issue at all. ${ }^{16}$ Last year, a District Court judge was able to conclude that a law banning flag-burning - only the burning of a New Zealand flag, that is, and without any requirement that anybody be endangered - was a law demonstrably justified in a free and democratic society. ${ }^{17}$ The Film and Literature Board of Review's standard consideration of the BORA is boilerplate. The searching tests laid down by the Court of Appeal to evaluate the propriety of restrictions on rights are seldom mentioned in media law cases at all, ${ }^{18}$ and seldom adequately dealt with when they are mentioned.

12 Burrows and Cheer, above $\mathrm{n} 3, \operatorname{ch} 8$.

13 New Zealand Bill of Rights Act 1990, s 14

14 Burrows and Cheer, above n 3, 650.

15 Burrows and Cheer, above n 3, 645.

16 TVNZ v Newsmonitor Services Ltd [1994] 2 NZLR 91 (HC).

17 Police v Hopkinson (6 November 2003) DC WN CRN38500960-2, para 30 Judge Noble, though France J took a different view on appeal: Hopkinson v Police [2004] 3 NZLR 704 (HC).

18 Moonen v Film and Literature Board of Review [2000] 2 NZLR 9 (CA); Minister of Transport v Noort; Police v Curran [1992] 3 NZLR 260 (CA). 
Media Law in New Zealand contains dozens of examples of vexed statutory and common law issues whose resolution ought to be informed by the BORA: the width of copyright fair dealing exceptions; the proper interpretation of a suppression of a "report or account relating to the proceedings"; the application of defamation laws to satire, rumour, and suspicions; the question of whether a publication could ever commit contempt for prejudicing a judge-alone hearing; and so on. In contrast to the rigorous approach to such issues adopted in the United States, and, increasingly, in Canada, ${ }^{19}$ the analysis of our courts and institutions has been patchy at best and woefully inadequate at worst. One hopes that in later editions of this text, a burgeoning BORA jurisprudence will oblige the authors to include more on the BORA right to freedom of expression than a 10-page chapter at the end and a dozen other scattered references.

Until the law gets knocked into a more principled and coherent shape, however, this book's sage guidance and compendious catalogue of laws affecting the media remains indispensable.

19 See for example Nebraska Press Association v Stuart (1996) 427 US 539; and $R$ v Kopyto (1987) 62 OR (2d) 449 (CA) both in the context of contempt of court. 